\title{
Real estate cadastre - new challenges's
}

\author{
Jadwiga Konieczna, Agnieszka Trystuła \\ University of Warmia and Mazury, Prawocheńskiego 15 str. 10-724 Olsztyn, Poland
}

\begin{abstract}
The recent rapid development of information technology has brought about increased use of digital geographic information and GIS systems in all aspects of human activity, both locally and globally. This also refers to effective land administration in accordance with the sustainable development principles. Easy access to up-to-date and reliable information on real estate, actual and potential possibilities of its development is the basis for taking decisions related to optimal space use. The cadastre is an institution with several hundred years of tradition, providing information on real estate, originating from the need for taxes on held real estate to be collected by states. Because of its high practical importance, the real estate cadastre is continually corrected and changed. The directions of these changes and the creation of new visions and models result from legal and administrative conditions, society's need to access to information used in the expanding process of natural resource management as well as from the dynamic development of spatial information technology.

The aim of this publication is to present the developmental directions of the Polish real estate cadastre with special regard to the need for building a multidimensional (3D, 4D) cadastre and an analysis of factors affecting the dynamics of changes in the functioning of the cadastral system.
\end{abstract}

Keywords: real estate cadastre; multidimensional cadastre; GIS.

\section{Introduction}

Land is the basis of economic activities and serves as a resource which requires careful management and takes into account the welfare of future generations. The information infrastructure which supports the management process focuses on three elements: land ownership, value and use. Proper registration of plots of land with regard to these elements ensures safety of ownership, the appropriate management of both space and land and efficient tax calculation.

Information about land and its users is provided by an institution whose history goes back several hundred years, which was shaped under different historical, cultural, political and legal conditions, which originated due to the need to collect rent: the cadastre. The term "cadastre" means basically the same in each country: a register; however, the administrative solutions applied in various countries result in certain differences. Initially, cadastres were flawed because the data used in them were not too accurate. This resulted from various factors, for example, from a lack of precision of measurement techniques as well as the legal and organisational solutions which were far from perfect. There are no two identical cadastral systems, because a cadastre is a part of the social infrastructure in a country, each system has evolved and has its own characteristics. However, the basic idea of a cadastre remains unchanged, because it always answers three basic questions: where is the real estate property, what are its features in terms of its boundaries, area, type and quality and - in some cases what is its value.

\section{Historical aspects of the Polish real estate property cadastre}

Each well-organised state has a land information system which contains a physical and legal description of plots of land, usually called a cadastre. The need to organise such an institution arose several centuries ago, mainly from the need to collect taxes by the state. The essence of the cadastre is best conveyed by the following quote from the Napoleonic Code: "Cadastre as such may be regarded as the real Constitution of the Empire, that is, the actual guarantee of property and assurance of the obligations of each person, because once established with a confirmation of the lawful taxation, it

Corresponding author: Agnieszka Trystuła. E-mail address: agnieszka.trystula@uwm.edu.pl

http://dx.doi.org/10.3846/enviro.2014.218

(C) 2014 The Authors. Published by VGTU Press. This is an open-access article distributed under the terms of the Creative Commons Attribution License, which permits unrestricted use, distribution, and reproduction in any medium, provided the original author and source are credited. 
eliminates any fears about the possibility of arbitrary decisions taken by public authorities, which has always been an important issue and which has been the surest method of enforcing serfdom".

The real estate property cadastre in Poland, whose official name is "the land and building register", follows the pattern and experience of the cadastral systems applied in the neighbouring countries. The system evolved as a result of historical conditions and changes in the Polish political, legal and administrative systems.

After the partitions of Poland, the fiscal systems of the occupying states were implemented in the territory of Poland. After the war, there were two consistent and complete post-partition cadastral systems. The technical and descriptive documentation of the former Prussian cadastre, which covered $40 \%$ of the country, was implemented in the western and northern parts of the country, whereas the survey used under the former Austrian occupation, covering 14\% of the country area, was used in the south of the country [1]. The land occupied by Russia was not covered by a uniform cadastral system similar to either the Prussian or Austrian systems. Such areas relied on different documents in the form of maps on different scales as well as consolidation and division registers.

After World War II, the new borders of Poland were established. The changed territory of the country, migrations of the population within settlement campaigns, reclaiming recovered territories and the transformations of the rural areas following agricultural reform - all rendered the land use data obsolete. This hindered the process of solving agricultural policy and economic problems, planning agricultural production and establishing fair amounts of services to the state.

The current land register was largely developed in the years 1955-1975 based on the decree of 2 February 1955 on the land and building register [2]. The decree provided for uniformity and exclusiveness of the register records, their foundation on the soil quality classification maintained in a uniform manner for the entire country and it imparted the status of public law to the surveys contained in the register. According to the decree, the taxes and services, purchase and obligatory supply of food products, economic planning, entries in perpetual registers and satisfying economic needs could be based on the data on lands and buildings contained in the unified registers. Such data were obtained by direct measurement in the field and the existing land surveys, for example, the data from the Prussian and Austrian cadastres and post-consolidation maps. The ownership of a plot of land was treated marginally during the process of creating the register, revealing the holder in the documents and establishing property boundaries according to the actual holding, rather than according to the legal status. Since 1 July 1989, the principles of maintaining a land and building register have been regulated by the Geodetic and Cartographic Act of 17 May 1989 (Journal of Laws 2010, No. 193, item 1287) and the executive regulations thereto: initially, the Regulation of the Ministers of Spatial Management and Construction and of Agriculture and Food Management on the land and building register of 17 December 1996 (Journal of Laws No. 158, item 813), and, subsequently, the Regulation of the Minister of Regional Development and Construction on the land and building register of 29 March 2001 (Journal of Laws No. 38, item 454).

According to Art.2.8 of the said act, the land and building register (the real estate property cadastre) is "a unified set of information about land, buildings and apartments/business establishments, their owners and other individuals or legal entities - holders of such land, buildings and apartments/business establishments". The 2001 regulation significantly expanded the scope of information contained in the previously-used land and buildings register and it became the basic legal tool in creating a modern resource of information about land, buildings and apartments/business establishments, as well as their owners and holders. This provided the basis for transformation of the existing register into the real estate property cadastre. The act made several significant changes relative to earlier regulations, which made it necessary to modernise individual elements of the register and created an obligation to record descriptive and geometrical data for buildings as well as descriptive data regarding apartments/building establishments.

Apart from the changed legal regulations, the real estate cadastre was affected by the political system transformations after 1989, which restored the due importance of the property rights. This resulted in implementing the constitutional protection of property rights as a fundamental feature of the political system. The transformation from a centrally-controlled to a free market economy entailed a range of changes in the social, economic and political situation of the country. A free market economy requires that all decisions regarding real estate management, both administrative and economic, should take into account the fundamental factors, such as the value and property rights which make up a modern real estate cadastre.

\section{Trends in real estate property cadastre development}

The trends in changes and development of the real cadastre arise not only from new legal, economic and administrative regulations, but also from society's need for access to spatial information to solve the emerging problems of globalisation, sustainable development, crisis management and environmental protection.

The first cadastral systems were closely connected with the first national fiscal systems and arose from the need to unify various tax systems. Identifying the owners of real estate and recording the rights as well as burdens and easements established on a real estate property was the aim of implementing the legal regulations which applied to real estate property. The land surveys performed for the cadastres helped to identify a real estate property clearly and to define its features, purpose and method of use. Therefore, different models of cadastre have developed:

- fiscal cadastre - focused on securing tax revenue due to the ownership of a real estate property, using current data from the real estate cadastre to determine the amount of tax due; 
- legal cadastre - focused on securing trades in real estate, which contains entries associated with a real estate, limited with the rights in property and those encumbering the real estate property with debts and burdens;

- physical cadastre - focused on real estate property planning and management, which contains information characterising a plot, buildings, apartments/business establishments and data on owners and holders.

However, none of the cadastres could operate in its pure form, consistent with its name. The fiscal cadastre uses survey and legal data, the legal cadastre uses survey data and the survey cadastre uses legal data. These systems, which currently operate separately, make up a cadastral system, which should be understood as a set of data contained in these subsystems and the procedures associated with processing and exchanging data and making them available [3].

Currently the development of real estate property cadastre and creating its new visions and models arises from the needs of the society regarding access to information used in an expanding process of natural resource management and from dynamic development of spatial information technology.

Concepts have appeared for multi-task cadastres, a proposed "Cadastre 2014" and "sustainable land administration". These visions have radically changed the perception of the cadastre and its potential [4].

A contemporary cadastre is a system which is referred to as a multi-task or multi-function one. This arises from the nature of cadastral data, their universality and usability in various areas of economic and social life, to satisfy the needs of an increasing group of users. According to the Geodetic and Cartographic Act, register records provide the basis for spatial planning, land management, guaranteeing property rights, tax charges, generating statistical data and monitoring the real estate property market. These functions demonstrate how the cadastre has been a multi-task instrument since its creation. Being a separate, autonomous system, a cadastre provides individual and collective users with primary (reference) information about: the location of a real estate property, its method of use, value, technical data and legal status. Another aspect of using cadastral data involves applying the appropriate GIS tools and conducting various spatial analyses based on cadastral information, generation of graphic studies and preparing statistical sheets.

The multi-functionality of a cadastre can be considered in different aspects. Firstly, as the ability of a cadastre to satisfy its users' need for information, regarding:

- detailed location (flat coordinates X, Y, but also a descriptive identifier in accordance with the TERYT register),

- sizes and shapes of the objects in the register,

- basic natural and technical features,

- method of use,

- legal status.

Secondly, expanding the areas of use of cadastral data, for example in:

- spatial and economic planning,

- introducing and maintaining spatial order,

- managing problem areas,

- granting building permits,

- calculating damages in connection with the construction of linear technical infrastructure,

- acquisition of land for investment projects for anti-flood facilities,

- natural disaster risk management,

- foundations of proper crisis management,

- development of entrepreneurship,

- conducting spatial analyses and scientific studies.

The issues associated with the real estate property cadastre can now be seen in an international perspective. The directions of the cadastral systems were largely affected by the cadastre model entitled "Cadastre 2014, a vision of the future cadastral system", developed in 1994-1998 by the working committee of the Commission of the International Federation of Geodesists. The study affected the cadastral reforms in all countries. The following definition of cadastre was provided in the study: "cadastre is a valid system of information about land, based on plots of land, which contains a register of rights of property to land; it usually contains a geometrical description of plots of land in connection with other registers which describe the nature of such rights, such as the value of a plot and its changes. It can be established for fiscal purposes (such as valuation and objective taxation); for legal purposes (transfer of ownership); as an auxiliary measure in spatial management (for planning and other administrative purposes); it also helps to make development a continuous process and to protect the environment."

There are six statements which set forth the directions which should be followed in the development of future cadastral systems. They apply to such issues as [5]:

- taking into account the rights, obligations and restrictions within the cadastral system,

- the disappearance of a border between maps and registers,

- the cadastral system evolving from its presentation on maps towards developing a model of cadastral information,

- the disappearance of a cadastre on paper,

- the trend towards privatising the cadastre,

- efforts to make cadastre self-finance.

The "Cadastre 2014" vision has significantly affected the development of modern cadastral systems. As 2014 approaches, the following conditions face changes: 
- legal - the community legislation act regarding infrastructure for spatial information - directive no. 2007/2/EC "Infrastructure for Spatial Information in Europe" - INSPIRE,

- technological - the development of spatial information technology, GIS tools,

- environmental - globalisation, climate changes, sustainable development,

- the need arises for developing new principles for future cadastral systems.

\section{New challenges}

A real estate property cadastre is a database which is essential for all processes associated with space; therefore, including "the third dimension" in the cadastre is currently very important for the development of the cadastre in many countries. The concept of a 3D cadastre is associated with the dimensions of our reality. Using and developing the space "above" and "below" the ground arises from the need to develop urbanised space or the linear investments and the infrastructure facilities created "above" the ground.

Work is under way in Poland to create a 3D cadastre, based on the solutions adopted in other countries. To understand the concept of 3D cadastre properly, one should start with an analysis of the concept of a real estate property and its boundaries. According to the definition provided in Art. 46 of the Civil Code, a real estate property is a separate piece of land which is an object of property rights [6]. A real estate property is usually thought of as a plot of land on the surface of the Earth, including any buildings or other structures bound permanently to the ground. In fact, a plot extends above and below the earth's surface. This is also mentioned in Art. 143 of the Civil Code, which reads: "within the limits set forth by the socioeconomic purpose of the land, the ownership of the land extends to the space above and below its surface". Therefore, the boundaries of a real estate property delimit an area of space within which the owner, with the exclusion of other individuals, can exercise their rights; in particular, they can collect benefits, earn income and dispose of things within those boundaries. Hence, the boundaries of a plot are not, in fact, lines defined by boundary points, but vertical planes.

A real estate property can be considered in a physical and legal sense. A land real estate property is entered in a cadastre by a digital description of boundaries with flat coordinates X, Y (physical element). Horizontal boundaries define a real estate property as an area with assigned rights (legal element) in a two-dimensional system X, Y.

However, a land property is a three-dimensional structure, so it has its horizontal and vertical boundaries. Therefore, one should seek to answer whether a land property is a two-dimensional plane and the property rights extend to the space "above" and "below" the plane, or maybe it is a solid, and the boundaries of the property rights are defined by the boundaries of the solid [7].

The horizontal boundaries delimit only one area where property rights have their impact and it is not a problem to define the boundaries in the field, in a two-dimensional system, when the appropriate measurement techniques are applied. However, defining the spatial boundaries of a property is not so easy. Vertical boundaries of the space where property rights can be exercised - pursuant to Art. 143 of the Civil Code - arise from the socioeconomic purpose of the rights, which means that the owner of a land property can make use of the space above and below the land surface insofar as it is necessary to exercise their rights.

A 3D cadastre should provide for not only a possibility of registration of geometrical data regarding three-dimensional object in the register, but also of the rights with the temporal-spatial nature granted on a thing belonging to someone else. The duration of the right is a determinant of the permanence of an isolated register object and it defines the fourth dimension of a cadastre (4D) [8]. Therefore, a 4D cadastre is characterised by both spatial aspects and a temporal aspect.

3D geovisualization is one of the trends of GIS development which enables effective and impressive analysis and representation of the surrounding space [9]. It is therefore appropriate to require that the modern real estate cadastre supported by GIS technology is able to record the objects of the system not only in 2D, but also in 3D (points with known $\mathrm{x}$, $\mathrm{y}, \mathrm{z}$ coordinates), defining how high above and how deep under the land surface the right of property reaches.

The development of a concept for the database architecture, which is the key component of a multi-dimensional cadastral system, was preceded by the determination of its two main potential functions, i.e. the registration function and the analytical function. It should be added that the concept for the architecture of a multi-dimensional cadastral system in this study is a development of previous $2 \mathrm{D}$ solutions. Therefore, potential registration operations of a multi-dimensional database are the registration of legal status at different levels of real estate properties (on land and above and under its surface). Potential analytical functions include 3D spatial analyses of cadastral objects (among others, 3D modelling of buildings).

The value of each database is determined, among others, by its application for the accomplishment of different aims and the quality of the data it offers and not the IT tools used for its construction. Therefore, developing the concept of a multidimensional cadastral database, each user should be provided, among others, with:

- a location on a numerical map of 2D and 3D objects with determined legal status with attributes,

- adaptation of the descriptive base to the contents of the geometrical base,

- the possibility of combining data originating from different sources,

- protection of legal data while ensuring continuous updating of information about the spatial layout.

Figure 1 presents the schematic diagram of a multi-dimensional cadastral database which takes into account the scope of data and the sources of their acquisition important in the creation of the multi-dimensional cadastre, the structure of data layers and an analysis and reporting of the entered data. 

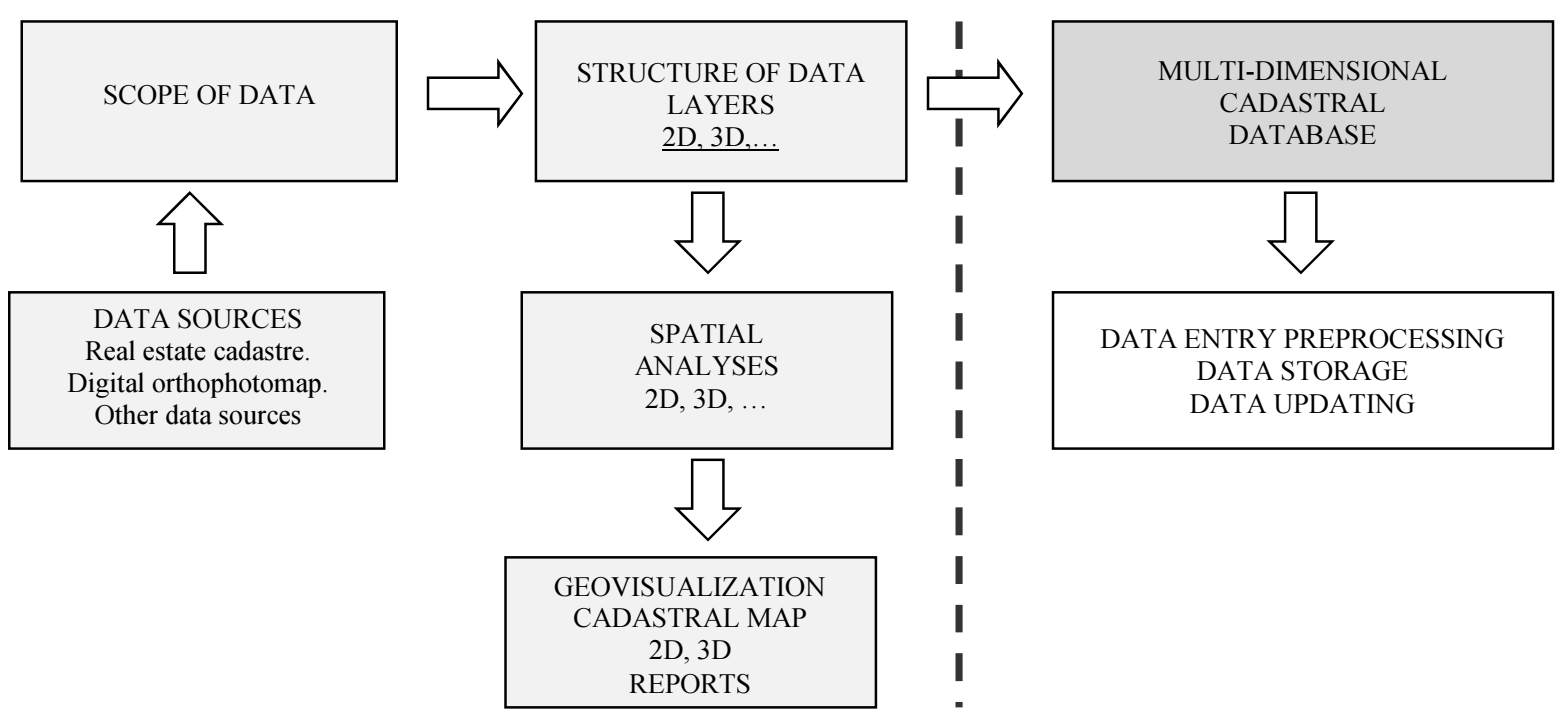

Fig. 1. Schematic diagram of a multi-dimensional cadastral database

The need to introduce 3D and 4D cadastres arises mainly from the need to use the space above and below the surface of a real estate property, especially for investment. Implementation of a multi-dimensional cadastre requires financial outlays, but it also necessitates changes in legal regulations and defining the concept of a spatial plot as the basic cadastral object and three-dimensional property rights. Such solutions will make it possible to register in a cadastre and to establish the legal status of buildings structures made above a property (bridges, flyovers, overhead roads) and under it (tunnels, underground railways, underground parking lots) by an investor other than the owner or a perpetual usufructuary. The addition of a temporal aspect will allow the changeability of spatial objects to be analysed in time and be forecast [10].

\section{Summary}

A practical use of a real estate property cadastre in different and expanding areas is the reason for countries making efforts to improve their systems of land management. This has been made possible by the development of information technologies in recent years, resulting in an increase in the use of digital geographical information and GIS systems in all aspects of human activities, both on a local and global scale. This also affects effective administration of land in accordance with the principles of multifunctional and sustainable development. Implementation of the right policy in different areas depends on the quality of information and the participation of society in its "creation" and use. Good quality spatial information is needed to understand the complexity of increasingly intensive human activities in the European Union, also taking into account its negative impact on the environment.

A new approach is needed to properly monitor the changes as well as data management and their transfer on different levels. The "value" of a system should be viewed from the perspective of a user, for whom important factors will include the quality, topicality of data, their accuracy, easiness to obtain and the possibility of integration. This will allow raw data to be used to create information to produce knowledge on the subject and form the basis for a decision, rather than the amount of such data itself. A property cadastre is a foundation which will meet the challenges of the future. Up-to-date and reliable cadastral data, integrated with information from other sources, will provide the basis for quick investments and appropriate spatial management.

\section{References}

[1] Goraj, S. 1982. Ewidencja gruntów. Warszawa: PWN. 420 S.

[2] Ustawa z 17 maja 1989 roku prawo geodezyjne i kartograficzne (Dz. U. z 2010 r. Nr 193, poz. 1287).

[3] Konieczna, J. 2003. Propozycja konstrukcji warstw informacyjnych katastru o wielu funkcjach. Rozprawa doktorska, Olsztyn.

[4] Karabin, M. 2013. Koncepcja modelowego ujęcia katastru 3D w Polsce. Warszawa: OWPW.

[5] Bydłosz, J. 2012. The Multi-dimensional cadastre around the world and its implementation conditions in Poland. Kraków: AGH.

[6] Ustawa z dnia 23 kwietnia 1964 Kodeks Cywilny (Dz. U. z 18 maja 1964 r., poz. 93).

[7] Matusik, G. 2011. Instytucje prawne pozwalające na korzystanie z przestrzeni „nad” powierzchnią gruntu, in Materiaty XX Krajowej Konferencji Rzeczoznawców Majatkowych. Katowice, 57-60.

[8] Felcenloben, D. 2013. Pojęcie działki przestrzennej jako obiektu przestrzennego umożliwiającego rejestrację trójwymiarowych praw do nieruchomości - kataster 3D, in Materiały XVI Konferencji Naukowo-Technicznej. Kalisz.

[9] www.24gis.pl - website viewed on 21.05.2011

[10] Konieczna, J.; Trystuła, A. 2013. Problems of the real estate cadastre against the background of economic, political, legal and technological transformations, Geomatics and Environmental Engineering 7(2): 79-87. 